\title{
What makes medical graduates practise close to home?
}

\section{John Wootton}

$\infty \quad$ See related article page 357

A $\mathrm{s}$ with sea turtles who disappear into the ocean from their natal beaches to reappear years later and be counted, it would be nice to radio-tag physicians to find out where they come from and where they go. The research reported by Mathews and associates in this issue ${ }^{1}$ does the next best thing: the authors trawled alumni lists and medical registers to see on what beaches former medical graduates of Memorial University of Newfoundland (MUN) eventually landed after residency training. It seems that, compared with earlier trends, fewer landed on beaches south of the 49 th parallel.

Health human resources research invariably tantalizes us with snippets of insight into a much larger and murkier reality. As Mathews and associates point out, it is good news that "in 2004 the number of physicians returning to Canada exceeded the number leaving the country." It is interesting also that they found that female graduates were I.44 times more likely than male graduates to be working in Canada in 2004, and a good thing, too, given the increasing numbers of female medical students. It is a tribute to MUN residency training programs that they attract (or select, or produce) trainees who are more likely to stay in Canada than those who leave "the Rock" after medical school to train elsewhere. However, these micro trends merely deal with the distribution of a limited physician pot. It is undoubtedly a good thing to maximize the proportion of Canadian-trained physicians who stay in Canada, and perhaps a good thing to increase the proportion who stay to practise in their province. The main issue, however, is not the proportion but, rather, the absolute number.

Health human resources researchers have borne much of the criticism for getting us into the shortage situation we now face. Barer and Stoddart in I99I proposed a series of measures to rationalize the delivery of health services. ${ }^{2}$ In their defence, limiting the number of physicians was not the only thing they proposed, but it was by far the easiest to implement, and we are now living with the consequences of the downsizing of the medical workforce into which all provinces bought. Add to this the effects of other less well understood societal trends, such as the desire for a "balanced lifestyle" and the "feminization" of the workforce, and the gap between the supply and the demand for services seems to inexorably widen. Hence we have the enthusiasm for fast-tracking foreign medical graduates into the workforce in many provinces and the rather belated increases in class size at the medical school level. That these increases have been only grudgingly implemented by governments is attested to by their tag, in Quebec, as nouveaux facturants (new billers).

Mathews and associates studied 2 outcomes: working in Canada in 2004 and working in Newfoundland and Labrador in 2004. What is interesting is the contribution of rural students to this cohort. Although other research has suggested that students from rural communities are more likely than those from urban communities to return to practise in rural settings, Mathews and associates' study suggests that they are also in general more loyal to the country that trained them even if their contribution is not necessarily rural. Since we also know that female physicians are less likely than their male counterparts to choose rural careers, these 2 trends together do not bode well for rural recruitment.

Unanswered in their research is the degree to which the findings are particular to Newfoundland, and to MUN. As an undergraduate, I was attracted to take an elective at that university because of the province's history, its remoteness and its mystery, and I have ended up in rural practice. It is anecdotal but perhaps important. Newfoundlanders and those attracted to Newfoundland may have other traits that make them more likely than others to stay in Canada. For years Newfoundland was characterized in the popular press as a "have not" province; however, that label did not refer to pride, friendliness or resourcefulness. Perhaps it is these qualities that we should be measuring as we choose the future doctors for Canada.

This article has been peer reviewed.

John Wootton is Scientific Editor of the Canadian Journal of Rural Medicine.

Competing interests: None declared.

\section{REFERENCES}

I. Mathews M, Rourke JTB, Park A. National and provincial retention of medical graduates of Memorial University of Newfoundland. CMAJ 2006;175(4):357-6o.

2. Barer ML, Stoddart CL. Toward integrated medical resource policies for Canada. Prepared for the Federal/Provincial/Territorial Conference of Deputy Ministers of Health. Winnipeg: Conference of Deputy Ministers of Health, Manitoba Health; June I991. Published in a 12-part series in $C M A J$ I992;I46(3) to 1993;I48(I).

Correspondence to: Dr. John Wootton, Box 70o, Shawville QC JoX 2Yo; john_wootton@ssss.gouv.qc.ca 